\title{
International Journal of Earth Science and Engineering
}

This new journal is being published once in two months by the CAFET-INNOVA Technical Society, to bridge the gap between Earth Sciences and the related civil, mining and mineral engineering disciplines. The Feb.2009 issue presents a lead article on Earth Sciences and Engineering, and nine supporting research papers. The opening introductory article on "the virtues of geosciences and their vistas in engineering" by SM Ramasamy and D. Venkat Reddy projects the impor-tance of field aspects of geomorphology, lithology and structure in natural resources assessment and management, and related environmental problems. Of the nine research papers, four come under the category of engineering geology, two under economic geology and one each under sedimentary petrology, strength of material and stress analysis in a coal mine. Besides, at my request, the chief editor, Prof. D. Venkat Reddy, agreed to publish my Book Review of "The Geology of India" by M. Ramakrishnan and R. Vaidyanadhan. The articles in this issue are well researched and peer-reviewed. We welcome this new journal and hope that the printing along side illustrations and colour photographs, would continue to improve further.

IIT Campus, Powai

S. VisWANATHAN

Mumbai -400076 